\title{
Intermedia Agenda Setting and Grassroots Collectives: Assessing Global Media's Influence on Greek News Outlets
}

\author{
Lambrini Papadopoulou ${ }^{1}$, Karolos Kavoulakos ${ }^{2}$, Christos Avramidis ${ }^{3}$ \\ ${ }^{1}$ School of International Studies, Communication \& Culture, Panteion University of Social \& Political Sciences, Athens, \\ Greece \\ ${ }^{2}$ School of Political Sciences, Aristotle University of Thessaloniki, Thessaloniki, Greece \\ ${ }^{3}$ School of Political Sciences, Panteion University of Social \& Political Sciences, Athens, Greece \\ Correspondence: Lambrini Papadopoulou, School of International Studies, Communication \& Culture, Panteion \\ University of Social \& Political Sciences, Athens, 136 Syngrou Av., 17671, Greece.
}

Received: June 10, 2021

doi:10.11114/smc.v9i2.5260
Accepted: July 29, 2021

Online Published: August 3, 2021

URL: https://doi.org/10.11114/smc.v9i2.5260

\begin{abstract}
This study focuses on a variety of grassroots collectives that emerged during the Greek economic crisis and aims to record activists' own perceptions regarding the way that domestic media reacted after these collectives featured on the front pages of global news outlets. Drawing on 10 in depth interviews with activists participating in five grassroots collectives, this study brings together social movement and communications theoretical frameworks. Interviewees were asked about their perceptions regarding the role that global elite media coverage may have played in the salience of their endeavors in domestic media. Subsequently, we tested their personal testimonies by implementing a time series analysis on three Greek newspapers for a period of seven days before and after a front page publication in global elite media. Findings suggest that there is a big discrepancy between the perceived and the actual impact of global elite media on the agenda of domestic newspapers. To this end, further research should be undertaken to specify the exact characteristics that influence which grassroots collective will gain prominence in the public realm.
\end{abstract}

Keywords: intermedia agenda setting, grassroots collectives, activists, perceptions, media, Greece

\section{Introduction}

Global elite media, such as the New York Times, have been demonstrated to exert a strong influence on the agendas of other news outlets, a phenomenon widely known as intermedia agenda setting effect (Denham, 2014; McCombs, 2014; Meraz, 2009). Most intermedia agenda setting studies have adopted quantitative methods to showcase that when a story is featured on the front pages of a global medium, it has more chances to find its place in other -national or internationalnews outlets that will change and adjust their content to match the coverage depicted in high status news organizations (e.g. Conway et al., 2015; Heim, 2013; Golan, 2006).

But how do the actual participants in these news stories perceive and experience this change in domestic media coverage? This question lies at the heart of this study which aims to focus on the activists participating in five Greek grassroots collectives that emerged during the economic crisis, using in-depth interviews to assess their perceptions of the way(s) that domestic media reacted after those collectives featured the front pages of global elite outlets.

The term grassroots collectives is employed in this study as an umbrella term to refer to the diverse citizen initiatives such as social clinics, takeovers of factories, social soup-kitchens and others, that emerged bottom-up, aiming to show solidarity to those most affected by the Greek crisis and to provide creative answers to the austerity policies.

Research on the intermedia agenda setting effect in the context of Greek media, especially with an emphasis on the coverage of grassroots collectives, is quite scarce. Roberts \& Bantimaroudis (1997) were among the first to demonstrate Greek media's reliance on international media sources and therefore, intermedia agenda setting influences. Specifically, they used in-depth interviews with twenty-five editors and journalists representing six elite media and they found that Greek editors rely mostly on Greek sources, although European influences are not negligible. Vamvakas and Dimitrakopoulou (2015) focused their research on the case of the Greek Indignant Citizens Movement (The Indignants) and their protests during the summer of 2011 through their portrayal in the Greek newspapers and blogs seeking to find 
whether online media and traditional media meet, overlap or compete with regard to their projected representations and ideological schemes. Doudaki (2011) focused her research on the swine flu disease and she found that the Greek and Cypriot media largely adopted the dominant discourse on the swine flu issue, reproducing foreign media's official language, arguments and framing of the event.

Notwithstanding the importance of these studies, there is still a gap regarding the Greek media reactions when global media pay attention to local collectives. Greece, as a case study, is quite interesting and deserves special attention as it is a country that was hit very hard by the economic crisis and its media struggled to offer support to the neoliberal austerity policies imposed by the government and at the same time silence any voices of resistance and dissent (Papadopoulou, $2020 ; 2019)$.

Grassroots collectives, almost by definition, do not have an institutional power base and lack financial resources. Consequently, they have to struggle harder to gain local media's attention (Gamson \& Wolfsfeld, 1993; Walgrave \& Vliegenthart, 2012). Moreover, as they typically employ a strong anti-hegemonic stance towards the mainstream status quo and the austerity policies, domestic media are less inclined to offer a favourable -if any at all-coverage.

Therefore, bearing in mind that almost by default, Greek media are not inclined to cover stories that may defy their own narratives, it is quite important to research whether they change this attitude and adjust their agenda when a local collective features on global media's front pages. Most importantly, it is of great importance to let the activists participating in these collectives share their own perceptions and experiences of this shifting attitude.

\section{Literature Review}

\subsection{The Determinants of Social Movements Coverage}

When researching the relationship between media and newsworthy events, one of the first question that comes to mind is 'what determines whether a story will receive attention from media?' To answer this question, Shoemaker \& Reese (2013), have suggested a set of criteria such as timeliness, novelty, proximity to audiences, national interest, controversy or conflict, journalists' professional and newsroom routines, as well as organizational imperatives.

When it comes to deciding whether a social movement will make it to the headlines, however, mainstream media seem to be susceptible to various ideological biases (Maniou, 2017; Papadopoulou, 2015; Gitlin 2003). In some cases, the bias against activist groups/movements is caused not only by fear of disrupting the normalcy within which networks usually operate but also by the uncertainty of change that such groups might impose.

As a result, media tend to neglect, downplay, or distort public protest activities (Rucht, 2003). This kind of coverage that marginalizes activist groups and casts the entire movement in a negative light, results in undermining grassroots collectives and reinforcing the main political status quo (Gitlin, 2003; Smith et al., 2001).

The emergence of digital media and communication technologies such as social media applications, as well as the development of new concepts such as citizen journalism, have played a crucial role in social movements' efforts to overcome these obstacles, communicate independently across time and space and mobilize support. Specifically, as Maniou and Bantimaroudis (2021) point out the hybrid nature of this complex, often chaotic, media system offers a sense of empowerment to new political actors while disempowering established political players and institutions. Grassroots groups and activists benefit from this new fluidity and openness.

However, according to Cammaerts (2018) social media are also characterized by a set of systemic limitations that must be acknowledged. For instance, he argues that while social media platforms are often heralded as liberal spacesadvocating freedom of speech, facilitating democratic struggles against authoritarian regimes, and supposedly even fueling revolutions, when it comes to radical protest in Western democracies, social media platforms can readily become illiberal and highly restricted spaces. The justification usually offered by internet companies for such repressive actions relates to breaches of their opaque terms and conditions of use (Cammaerts, 2018, p. 170). Notwithstanding social media's role, many social movement scholars and activists point to the continuing importance of the mainstream media for communicating beyond the like-minded, in particular when it comes to the logic of disclosure and efforts to circulate movement discourses and frames (Cammaerts, 2013; Gamson \& Wolfsfeld, 1993). Specifically, Rucht (2013, p. 262) argued that, despite the emergence and increased importance of the internet, ' $[t]$ o reach the public at large, the key channel was and is getting access to and coverage by the established media'. Their importance is also acknowledged by activists themselves through their various attempts to manage journalists and influence their own media representations positively (Cammaerts, 2018).

\subsection{Agenda Setting Theory and Intermedia Agenda Setting}

Before delving into the issue of intermedia agenda setting, we must first begin with a short introduction of the phenomenon of agenda setting which dates back to 1972 and specifically to the first agenda-setting researchers, McCombs and Shaw 
(1972). In their seminal Chapel Hill study they found that the public's perception of the relative importance of issues is determined to a great degree by the amount of media coverage devoted to issues. This was a sharp break from the previous media effects studies that had focused on what people thought (their opinions and attitudes) and on behaviors such as voting. After this initial study, agenda setting has emerged as a prominent theory in the field of media studies, and there have been several studies carried out by scholars focusing on the relationship between news media ranking of issues and public rankings of the perceived importance of these issues (Weaver, 2016; Bantimaroudis, Zyglidopoulos \& Symeou, 2010).

Since then, studies went beyond the initial relationship that assessed media and public salience and observed that the media often set agendas for other media within national or international media contexts and that in many cases, regional media replicate the major headlines of national media for their public (Bantimaroudis, 2017). Intermedia agenda setting effect, a term coined by Danielian and Reese (1989) refers exactly to the way media can influence other media in terms of issue salience.

More specifically, high status news organizations, such as The New York Times and Associated Press, set the agendas of other news organizations that monitor and often adjust their coverage to match those of global elite news media; on the local level, local newspapers and television stations influence the news agenda of their competitors (McCombs, 2014; Danielian \& Reese, 1989; Whitney \& Becker, 1982).

For instance, Danielian and Reese (1989) found that television takes its cue on the salience of the drug issue from newspaper coverage. Trumbo (1995) found that global warming news coverage in traditional print news media including The New York Times, Wall Street Journal, and Washington Post, influenced the agenda of national broadcast media. In his research, Golan (2006) found significant correlations between the international news agenda of the morning New York Times and the international news agendas of three evening television news programs. As a result, he argued that inter-media agenda setting should be considered in future studies on the international news selection process.

High status media such as NYT and their impact on news outlets all over the world have been the focus of numerous of studies over the years. However, it should be emphasized that the intermedia agenda setting function of elite media is not limited to USA's high status media. Researchers have also tested this phenomenon in a wide range of countries. For instance, Lopez- Escobar et al. (1998) focused their research in Spain, whereas Lee et al. (2005) researched Korean newspapers.

Over time, technological innovations led to the availability of online news media and social media. Scholars have gradually introduced those in the existing inter-media agenda setting framework demonstrating two-way agenda-setting effects between traditional and newer media forms (Neuman et al. 2014; Messner \& Distaso 2008). For instance, Messner and Garrison (2011) found that blogs are starting to exert an influence on the news media agenda. Ragas \& Kiousis (2010) have also incorporated online news media into the existing intermedia agenda setting studies. Nevertheless, these major shifts in the ways people process information have not completely deprived mainstream media of their ability to set agendas for the masses (Bantimaroudis, 2020). Both in their traditional form (Rogstad 2016; Groshek \& Groshek 2013; Lee, 2005) and via their online channels (Ceron et al. 2016; Vonbun et al. 2016), they established that media titles still shape the news discourse.

\subsection{The Greek Crisis and Collective Action}

Social movements, collectives and groups of various kinds have been active in Greece long before the economic crisis, however, the country's acute economic problems and the subsequent austerity measures that affected every facet of society, marked the beginning of a protest cycle characterized by a multitude of social movements (Papadopoulou \& Maniou, 2020; Serdedakis \& Tompazos, 2018; Kousis \& Kanellopoulos, 2014; Afouxenidis \& Kavoulakos, 2012; Psimitis, 2011).

These initiatives had as a goal the creation of relationships that cover social needs (Kavoulakos, 2018; Kavoulakos \& Gritzas, 2015) engaging in what Zamponi and Bosi (2018) termed as "direct social action". These initiatives, adopted a strong anti-hegemonic stance towards the mainstream status quo and the austerity policies. Guided by autonomy, solidarity, and responsibility, they included takeover of factories and self-organized initiatives of food and goods distribution that eschewed middlemen to both farmers'/producers' and consumers' benefit, local currency schemes, social groceries and pharmacies, as well as social soup-kitchens and even social clinics. The range of similar initiatives was enormous and enveloped the country.

Our research focuses on some of these initiatives which may have emerged under the same circumstances but they are so diverse in terms of goals, scale, participants, and practices that do not allow for clear categorizations and cannot easily fall under a specific term or definition. This challenge is not new in the field. Previous studies have suggested a variety of terms such as alternative action organizations (Zamponi \& Bosi, 2018), alternative forms of resilience (Kousis \& Paschou, 2017), social movement campaigns (Staggenborg \& Lecomte, 2009), social movement community (Staggenborg, 1998; Taylor \& Whittier, 1992) campaigns (della Porta \& Rucht, 2006), solidarity initiatives (Daskalaki \& 
Kokkinidis, 2017), and others. Marwell and Oliver (1984) even characterized the effort to define social movements as a 'theoretical nightmare'. Moreover, as the number of these endeavors increases, so does the number of theoretical approaches that scholars apply to study them (Kousis \& Paschou, 2017).

Although this study acknowledges the inherent difficulties and challenges in an effort to map this field, engaging in this discussion or providing a new definition is far from the aims of this paper. To this end, for the purposes of this study, we decided to adopt the notion of grassroots collectives as an umbrella term. This notion embraces the diversity of collective citizen initiatives that emerged bottom-up, often driven by necessity, are self-managed and aim to provide creative answers to the austerity policies and multiple compound inequalities.

\section{Research Question and Method}

Bearing the above in mind we aim to provide answers to the two following questions:

RQ1: How do activists participating in various Greek grassroots collectives perceive the role of global elite media?

RQ2: Is Greek print media's agenda influenced by global media's coverage of the country's grassroots collectives?

Most intermedia agenda setting studies have adopted quantitative methods (for example, Conway et al., 2015; Heim, 2013; Golan, 2006). Following recent literature's calls for the integration of interviews (Ragas \& Kiousis, 2010) we apply a methodology that combines tools from both quantitative and qualitative analysis. This combination was necessary in order to map the possible discrepancies in the perceived and actual role of foreign elite media in Greece's news outlets.

\subsection{In-depth Interviews}

Della Porta (2014) has pointed out that in-depth interviews help researchers pay more attention to people's interpretations of reality and in this sense, they have contributed to theory building, but also to theory testing. Moreover, Roberts and Badimaroudis (1997) stressed that in-depth interviews are proven to be the most efficient and effective method of acquiring the true opinions of the interviewees. Bearing the above in mind, we began our research by interviewing activists participating in five grassroots collectives in order to record their own perceptions about the role of global elite media in the salience of their collectives in the domestic news outlets.

The interviews took place during July -September 2019 and lasted for about 60 minutes. To ensure that our findings were reliable, we refrained from asking them specifically about the role of global elite media. On the contrary, we initiated our interviews by asking them to (1) describe their experiences regarding the way Greek media covered their collectives and (2) specify any turning point they might have encountered in the way Greek media covered their collectives. In this way, we made sure that they were not urged to speak specifically about global elite media. However, when they did mention high status media in their narratives, we asked them to elaborate on the role that these media played in the prominence of their collectives in the Greek media sphere.

The selection of the interviewees was based on two main criteria: their seniority in the grassroots collectives and their role in them. We specifically contacted founding members as well as key- members that were very active in the collectives and thus, could offer a broad and deep insight into the issues that our study deals with. Subsequently, we analyzed these interviews through a thematic analysis, which is considered to be one of the most common forms of analysis in qualitative research and a theoretically flexible method that organizes, describes, and interprets qualitative data (Braun \& Clarke, 2006). Specifically, to analyze the interview data, we followed the six-phase procedure suggested by Braun and Clarke (2006): (1) become familiar with the data, (2) generate initial codes, (3) search for themes, (4) review themes, (5) define themes and (6) write up.

\subsection{Time Series Analysis}

After analyzing the data from our interviews, we wanted to put those findings to the test and find out if the activists' perceptions about the impact of global media on Greece's news outlets actually coincided with the context in the country's newspapers. To do so, we adopted a time series analysis and researched the actual impact that global foreign media had on Greece's news outlets. Specifically, we traced the first time each of the under research collectives made it to the headlines of global elite media, as empirical findings suggest that high status newspapers like e.g. The New York Times are the most important intermedia agenda-setters (Danielian \& Reese, 1989). Using each of these front pages as a reference point, we searched for the kind of impact they had on three Greek newspapers for a period of seven days after their publication. To test our findings, we also searched for possible related stories in the Greek media for a period of seven days prior to the global publication. We focused our research on three print media websites: Kathimerini, which is a Greek conservative leading newspaper, Protothema, a populist Sunday newspaper with the highest circulation and Naftemporiki, a leading financial newspaper. For each collective, a set of relevant keywords was selected to search the number of articles in the databases and to ensure that only articles that are actually about the particular collective were included in the analysis. This methodology was considered significant as it helped us put the findings from the in- depth interviews into perspective. 


\subsection{The Grassroots Collectives}

This research focused on a variety of grassroots collectives that were active in different fields ranging from work and health, to food markets, and environment. Our case studies may show differences in terms of aims, structures, visibility in the public realm and scope of action, but it is exactly this diversity that will allow us to paint the whole picture of the field. Moreover, despite their differences, they all lasted for a great amount of time and their actions were emblematic in their field. While it cannot be claimed that these initiatives are exhaustive of the whole field, they are however suggestive of the main dynamics and critical approaches that emerged in the context of the current crisis.

- The Metropolitan Social Clinic at Helliniko is a volunteer-run solidarity social clinic that was created in 2011 as a response to the dismantling of the Greek public health care system. It aims to provide free primary medical care and medication to all uninsured, unemployed, and needy patients. The Metropolitan Social Clinic at Helliniko is considered a model for a radical solidarity action and it is widely studied as an example of the emerging civil society's alternative model (eg. Kotronaki \& Christou, 2019; Evlampidou \& Kogevinas, 2019; Adam \& Teloni, 2015).

- Vio.Me is a factory in Thessaloniki that used to make chemical products for the construction industry. It got under the control of its workers in 2013 when it went bankrupt. Vio.Me is the only occupied factory in Greece and thus it became a reference point for radical social action and it gained a lot of visibility (eg Kokkinidis, 2015; Kretsos \& Vogiatzoglou, 2015).

- The Skouries anti-mine movement is a local environmental movement in northern Greece organized by residents and activists that are opposed to the gold mining operations that are taking place in the area. Literature has focused its attention on Skouries, and its struggle against the exploitation of common resources (Tsavdaroglou et al., 2017; Calvario et al., 2017; Avramidis \& Pelekanidis, 2016).

- Without middlemen are initiatives all over Greece that organize local markets where farmers can sell their products directly to consumers at a price that is much lower than the standard market price. The first initiative emerged in February 2012 in the town of Katerini, and it rapidly spread across the country. Without Middlemen is widely studied in the context of social struggles that challenge the capital-state nexus (e.g. Calvário et al., 2017; Avramidis \& Galanopoulos, 2013).

- The struggle of the 'cleaning ladies' is a group of nearly 600 female cleaners who were sacked after years of work, following the public-sector cuts demanded by Greece's creditors. They refused to leave quietly and camped outside the finance ministry building in central Athens, fighting riot police and braving a host of administrative and repressive measures for nearly two years, until rehired by the SYRIZA government. This struggle stood out by creating a permanent camping protest space and it became a symbol of resistance against austerity policies (Daskalaki \& Fotaki, 2017; Panayiotakis, 2015).

\section{Findings}

Initiating with our interviews, four main themes were found and defined. These themes analyzed below, unveil activists' perceptions regarding the role that global elite media played in the salience of their collectives in the Greek media.

\section{Indifference as a Means of Silencing}

The first theme that emerged was indifference as a means of silencing. During the first months of their existence, most grassroots collectives tried to gain media's attention in order to spread their message and mobilize the public. After all, as many studies have shown, mainstream media's attention validates the existence of a movement and creates a kind of common understanding and knowledge that can be used by social movements to mobilize and make sure that the public and movements speak the same language (Rohlinger, 2002; McCaffrey \& Keys, 2000; Gamson 1995; Gamson \& Wolfsfeld, 1993).

Bearing the above in mind, our respondents sent e-mails, press releases, and tried to directly contact journalists in various organizations. However, as one of the interviewed activists put it.

It felt as if we didn't exist. We had tried to contact some media organizations and ask them to present our collective action so that more patients would learn about it, but there was no interest at all. They just ignored us (G.V., personal interview, June 4, 2020).

Our respondents attributed this dismissive attitude to a conscious effort to render their grassroots collectives invisible and prevent their message from getting across to a wider audience. As one of the respondents explained:

You ask why media paid no attention to us. Because their bosses told them that things like that (mobilizations, occupations) do not get to be broadcast. So, it is only normal that they kept quiet. Perhaps in some cases, it wasn't the boss, but the head editor that gave the order. In any case, these things happen and we know that some journalists are only concerned about their own bosses' interests (M.A., personal interview, June 5, 2019). 


\section{Foreign Media as Catalysts}

After several months in total obscurity, our respondents witnessed a sudden shift and found themselves in the center of the media's attention. As they pointed out, foreign media played a catalytic role in this change since they not only took notice of the local struggles but they also devoted time and energy to report on them. As one of the activists explained:

We saw Al Jazeera, The New York Times, Süddeutsche Zeitung, RTL, Tv crews from Netherland, Serbia... you name it. NYT even featured us on their front-page (I.T, personal interview, June 6, 2019).

This sudden interest was a great surprise for the respondents, one of them described it as a shock:

In the beginning, it was shocking that people from Canada, Germany, Turkey and other places all over the planet would come here and show real concern and interest about our problems (M.K., personal interview, June 7, 2019).

Apart from providing space and time, foreign media functioned as 'game changers' since according to our participants, their continuous interest forced Greek media to shed light on these movements and stop acting as if they were invisible. This pivotal role is described eloquently by one of the respondents who refers to this moment as a turning point

That change took place during the summer of 2012 after New York Times featured us on their front page. I remember that the day after the publication, there was a 'storm' of phone calls from journalists all over Greece. One month after NYT, CNN also wrote an article about us that was quite good and extensive. Well, after that there was a huge interest from all media all over Greece (G.V., personal interview, June 4, 2019).

This finding is of great importance, since it records, for the first time, the intermedia agenda setting phenomenon in the context of the grassroots collectives. As one of the participants pointed out, it wasn't until the elite media with global recognition devoted time and space to their struggles that the local media also started taking notice of them and acknowledging their existence.

When media such as the New York Times write for a local struggle, how can domestic media turn the other way around and ignore us? How could they justify such a decision? How could they hide the foreign front pages and pretend they didn't happen? They just can't. (E.A. personal interview, June 8, 2019).

Indeed, in some cases, Greek newspapers replicated global media's front pages pointing out that a particular Greek collective made it to the headlines of high status media. For instance, a day after The struggle of the 'cleaning ladies' was featured on the front page of the international edition of The New York Times, Kathimerini, a Greek well-esteemed newspaper wrote an article pointing out that «The struggle of the 'cleaning ladies' who become symbols of resistance against austerity measures, star in the most extensive article on Greece in the international edition of the New York Times» (Kathimerini, 2014).

\section{Distortion and Censorship}

Despite their initial surprise, our respondents soon realized that Greek media's attention wasn't what they had struggled for and what they were expecting it to be. Each participant in our research shared stories of distortion and censorship initiated by private and public media organizations to frame their messages according to their interests and narratives. For instance, one of our respondents explained:

They (Greek media) would distort our interviews, our statements, the number of (people) who participated in the demonstrations to support us, even the way things took place. They would make sure to send a camera every time we received a lawsuit but they never wrote a single line whenever the courts found us non-guilty (M.K. personal interview, June 7, 2019).

This statement is particularly true for the Skouries anti-mine movement which organized regular protests. Despite the large amount of people who joined these protests, in some cases, mainstream media would downplay the number of participants.

Another one described various incidents of interventions in his interviews while he was criticizing the government's health policy:

I remember one time that I was invited to talk to a TV- show and when they realized what I was going to say they asked me to talk only for two minutes and they stopped me after just one minute. In another instance, I was talking on a radio show about the responsibilities that the PM and minister of health had and suddenly the producer received a phone call and stopped the interview. (G.V. personal interview, June 4, 2019).

The rest of our participants reported similar incidents of censorship, as well as of aggressive behavior, by the media.

For instance, a particular tv channel that has very close ties with the right- wing government would try to ridicule and make fun of the Without middlemen collective by describing their local markets as fun fairs where people were humiliated by pushing each other and fighting over a bag of potatoes. 


\section{Back to where it all started}

The final theme that emerged was Back to where it all started. At this point, our respondents described that Greek media's attention subsided when journalists realized that activists would not adhere to their own rules and accept being framed according to each media's own interests.

In this context, as one activist stressed, Greek media turned their backs to them to silence them and render them -once more- invisible.

Every media outlet that approached us, disappeared when it realized that we were not aligned with their philosophy and interests. They never called us again. [..] so they went back to ignoring us, being completely indifferent. We ended up exactly where we had started. Yes, they stopped dealing with us because they no longer wanted to present what we were showing (G.V. personal interview, June 4, 2019)

In a quite revealing quote, one of the interviewees highlighted the sudden and ultimate shift of media attention:

They used to provide time and space to us every time we had a demonstration. We were bored of seeing them again and again and then suddenly, after a point they all disappeared. All the stories on TV stations, all the articles in the newspapers. We disappeared [..] and actually, people living outside of Chalkidiki, who used to watch our struggle from media, started saying "so, is the issue solved now? We don't see it on the news so it must have been solved" So media cultivated this understanding, that the issue doesn't exist anymore, the reactions have stopped, the issue is solved and this is why it no longer appears on the news. However, of course, the reality was far from this (M.K. personal interview, June 7, 2019).

\section{Results}

To test the above findings that pointed us towards the direction of the intermedia agenda -setting effect, we subsequently employed a quantitative methodology. Specifically, we traced the first time each of the under research collectives made it to the headlines of global elite media. Using each of these front pages as a reference point, (indicated as 0 in Figure 1.) we searched for the kind of impact they had on three Greek print media for a time period of seven days. Moreover, we researched for possible mentions for a period of seven days prior to the global front page story (Figure 1).

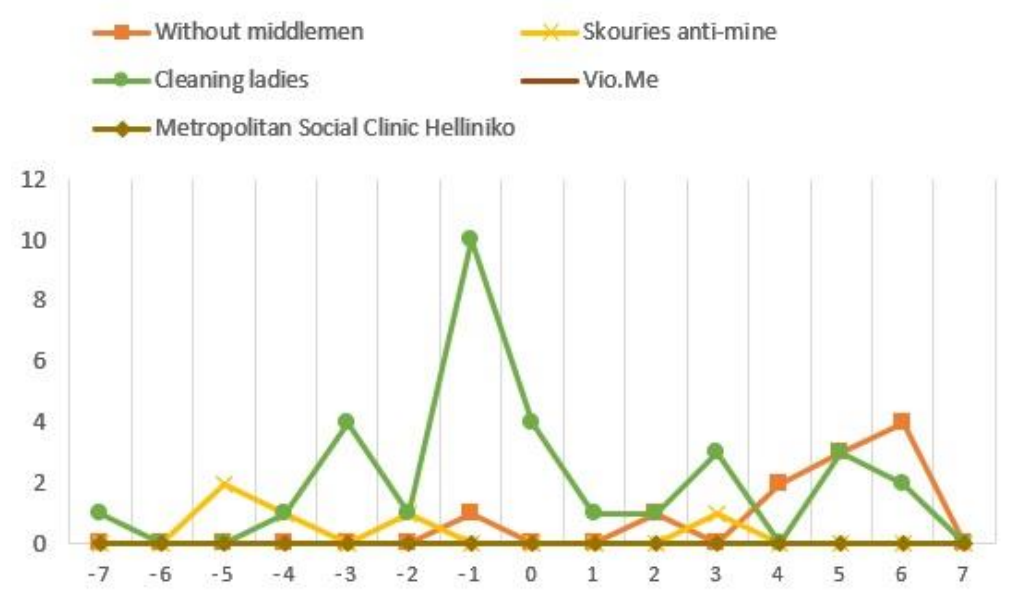

Figure 1. The impact of global front pages on the agenda of Greece's news outlets

Our analysis, as presented in Figure 1. revealed some quite surprising findings. Contrary to what the activists described, we found relatively little-if any- evidence that Greek print media actually monitored and adjusted their agenda to the elite media's front pages regarding those collectives. Specifically, we found no reference whatsoever before or after the global publication for two of our under research collectives, The Metropolitan Social Clinic at Helliniko, and VIOME. With regards to Skouries, we found four stories in the Greek newspapers during the week prior to the foreign story and only one story after the foreign publication.

Our next collective, The struggle of the cleaning ladies featured 24 times in the Greek print media before the foreign publication and 10 times after it made it to the global headlines. The only collective that actually gained more visibility in Greek newspapers after the foreign publication was Without Middlemen that featured one time in the domestic print media prior to the publication and eight times after it had made it to the global headlines.

\section{Discussion}

Initiating from a qualitative methodology, this study aimed at recording activists' personal experiences of the way that Greek media covered their grassroots collectives and the role that global elite media may have played. By doing so, we managed to document, for the first time, a specific repertoire adopted by Greek mainstream media when covering grassroots collectives. 
This repertoire comprised of four stages (1) Indifference, (2) Foreign media as catalysts (3) Distortion and censorship (4) Back to where it all started. According to their testimonies, Greek media's attitude was dismissive in an effort to silence them and render their struggles invisible for the wider audience. When asked if they noticed any turning points in this dismissive attitude, they all pointed out the catalytic role of global elite media arguing that when their endeavors featured in outlets such as The New York Times and The Guardian, Greek media began noticing them and devoting time and space to their collectives. Moreover, as they argued, after a while, when foreign media's interest subsided, so did Greek media's interest. This finding that is based on their personal experiences, essentially confirms the existence of the intermedia agenda setting effect in the context of the Greek grassroots collectives.

We subsequently put the above findings to the test by implementing a time series analysis methodology into the stories that featured in the Greek print media before and after the global publications. The results from this analysis provided us with a completely different point of view. As depicted in Figure 1. we managed to record the intermedia agenda setting effect only with regards to the Without middlemen collective. For the rest of the case studies, the stories featured in the global elite media made little- if any at all- difference to the salience of the under research collectives in the Greek newspapers.

\section{Conclusion}

The impact of global elite media on the agenda of domestic news outlets has been widely researched and discussed. Several studies have recorded the strong influence that media such as the New York Times have on the agendas of other news media outlets pointing out that the appearance of a particular story on their front page renders the topic as newsworthy for the rest of the media as well (Denham, 2014; McCombs, 2014; Meraz, 2009).

Notwithstanding their contribution to the field, it must be noticed that most of these studies focus their attention on analyzing the stories that feature in those media paying little -if no attention at all- to the actual people who participate in these stories and to the way(s) they experience media's shifting attention.

This study focused its attention on the activists participating in five Greek grassroots collectives using in-depth interviews to assess their perceptions regarding the way that domestic media reacted after their collectives featured on the front pages of global elite outlets. Our initial findings seemed to verify the significant role of global elite media, as all of the participants pointed out that domestic media started paying attention to them only after their collectives had made it to the headlines of global news outlets.

Subsequently, we used a time series analysis in three Greek print media to put those findings into perspective and we found out that things are more complicated. With the exception of one collective (Without middlemen) we didn't record any significant difference in the visibility of the rest of the grassroots collectives after they featured on the front pages of global media. In two specific cases actually (Viome and The Metropolitan Social Clinic at Helliniko), we found no reference at all before or after the global publication.

This discrepancy between the perceived and the actual impact that global elite media may have on Greek print media can be attributed to various reasons. For starters, activists' testimonies on the role of global elite media is directly connected with their own dismissive perception of Greek mainstream media. During the Greek crisis, mainstream media were perceived to intervene as active agents in the discursive struggles over the social construction of the crisis, reproduce the hegemonic discourse and privilege the political and economic elites in expressing their views while marginalizing or excluding counter-hegemonic or other alternative voices (Leandros \& Papadopoulou, 2020; Mylonas 2014). As a result, activists seem to have placed all their hopes and trust on global elite media, rendering them as 'objective' and 'trustworthy'. Thus, activists automatically interpreted Greek media's coverage of their struggles as a change brought about by the interest that high status media showed. This finding is of great importance since it records for the first time a unique way of thinking based on the assumption that mainstream media would provide time and space to collective grassroots only if they were forced by the visibility provided to those collectives by high status media.

Regarding the actual impact that these media had on the agenda of domestic print outlets, our findings leave little room for doubt; Greek newspapers were not influenced whatsoever by the global front pages featuring the country's grassroots collectives. This finding leads us to the assumption that Greek print media's ideological biases against the collectives that challenge the mainstream status quo were proven stronger than their will to monitor and adjust their agenda to global elite media.

To sum up, this study has suggested that there is a big discrepancy between the perceived and the actual impact that global elite media may have on the Greek media landscape when it comes to covering grassroots collectives. Notwithstanding the role of high status media that are described as the most important intermedia agenda setters, this study argues that in some cases, factors such as ideological biases and norms may overcome the prestige that global elite media, such as New York Times and The Guardian, carry. 


\section{Limitations and Future Research}

Our research is not without its limitations. Although a small number of interviews can hardly advance our understanding, we argue that our initial findings are quite representative of the main dynamics in this field. Nevertheless, a bigger sample would definitely lead us to more conclusive findings. Another issue that future research could address concerns the content of these media. How were these collectives framed in the global media? How were they framed in the domestic media? Are there any similarities? These are some of the questions that future research could focus on. Moreover, as our findings suggest, some of the collectives received some kind of acknowledgement in the domestic media whereas others were totally ignored, despite the global front pages. Consequently, future research should focus on the collectives that seemed to have benefitted the most from international media exposure and reveal the reasons behind this preferential treatment. Finally, it would be interesting to move this discussion to the social media realm and search for possible influences of international coverage on domestic social media discourses.

\section{Acknowledgements}

This research is co-financed by Greece and the European Union (European Social Fund- ESF) through the Operational Program «Human Resources Development, Education and Lifelong Learning 2014- 2020» in the context of the project "De-MEDIAting social movements in crisis-ridden Greece: A critical analysis of the communicative strategies adopted by social movements towards mainstream media and wider audiences".

\section{References}

Adam, S., \& Teloni, D. (2015). Solidarity Clinics in Crisis-ridden Greece: The Experience of Health Care Provision When Public Health Care is in Retreat. [In Greek] Studies Observatory of Social and Economic Developments, General Confederation of Greek Labour. Retrieved January 20, 2021 https://ineobservatory.gr/publication/kinonika-iatria-stinellada-tis-krisis-i-empiria-tis-parochis-ipiresion-igias-otan-to-ethniko-sistima-igias-ipochori/

Afouxenidis, A., \& Kavoulakos, K. (2012). New forms of political participation and mobilization via the use of social media in contemporary Greece. In IPSA XXII World Congress of Political Science.

Avramidis, C., \& Galanopoulos, A. (2013). Vio. Me: Labour experiment with worldwide resonance [in Greek]. UNFOLLOW Magazine, issue 15. Retrieved May 5, $2013 \mathrm{http} / / \mathrm{bit} . l \mathrm{l} / 15 \mathrm{kIzN}$

Avramidis, C., \& Pelekanidis, T. (2016). An ironical state of exception. The violation of Human Rights and the example of Skouries. In Conference Human Rights; Founding Myths and historical perspectives.

Bantimaroudis, P. (2017). Setting agendas in cultural markets: Organizations, creators, experiences. New York: Routledge.

Bantimaroudis, P. (2020). I Am the Agenda: Personal Salience, Agenda Selfying and Individual Name Building in Hybrid Media Settings. Studies in Media and Communication, 8(1), 1-10. https://doi.org/10.11114/smc.v8i1.4677

Bantimaroudis, P., Zyglidopoulos, S., \& Symeou, P. C. (2010). Greek Museum Media Visibility and Museum Visitation: An Exploration of Cultural Agenda Setting. Journal of Communication, 60(4), 743-757. https://doi.org/10.1111/j.14602466.2010.01512.x

Braun, V., \& Clarke, V. (2006). Using thematic analysis in psychology. Qualitative Research in Psychology, 3(2), 77-101. https://doi.org/10.1191/1478088706qp063oa

Calvário, R., Velegrakis, G., \& Kaika, M. (2017). The Political Ecology of Austerity: An Analysis of Socio-environmental Conflict under Crisis in Greece. Capitalism Nature Socialism, 28(3), 69-87. https://doi.org/10.1080/10455752.2016.1260147

Cammaerts, B. (2013). Networked Resistance: The Case of WikiLeaks. Journal of Computer-Mediated Communication, 18(4), 420-436. https://doi.org/10.1111/jcc4.12024

Cammaerts, B. (2018). The Circulation of Anti-Austerity Protest. Palgrave Macmillan. https://doi.org/10.1007/978-3-31970123-3

Ceron, A., Curini, L., \& Iacus, S. M. (2016). Politics and Big Data: Nowcasting and Forecasting Elections with Social Media. Taylor \& Francis.

Conway, B. A., Kenski, K., \& Wang, D. (2015). The Rise of Twitter in the Political Campaign: Searching for Intermedia Agenda-Setting Effects in the Presidential Primary. Journal of Computer-Mediated Communication, 20(4), 363-380. https://doi.org/10.1111/jcc4.12124

Danielian L. H., \& Reese S. D. (1989). A Closer look at Intermedia Influences on Agenda Setting: The Cocaine Issue of 1986. In P. J. Shoemaker (Ed.), Communication Campaigns About Drugs Government, Media, and the Public (pp. 6780). New York and London: Routledge. 
Daskalaki, M., \& Fotaki, M. (2017). The neoliberal crisis: Alternative organizing and spaces of/for feminist solidarity. In A. Pullen, N. Harding \& M. Phillips (Eds.), Feminists and queer theorists debate the future of critical management studies (pp. 129-153). Emerald.

Daskalaki, M., \& Kokkinidis, G. (2017). Organizing Solidarity Initiatives: A Socio-spatial Conceptualization of Resistance. Organization Studies, 38(9), 1303-1325. https://doi.org/10.1177/0170840617709304

Della Porta, D. (2014). In-depth interviews. In D. Della Porta (Ed.), Methodological practices in social movement research (pp 228-261), Oxford: Oxford University Press.

Della Porta, D., \& Rucht, D. (2006). The Dynamics of Environmental Campaigns. Mobilization: An International Quarterly, 7(1), 1-14. https://doi.org/10.17813/maiq.7.1.a2p473545718n577

Denham, B. E. (2014). Intermedia Attribute Agenda Setting in the New York Times: The Case of Animal Abuse in U.S. Horse Racing. Journalism \& Mass Communication Quarterly, 91(1), 17-37. https://doi.org/10.1177/1077699013514415

Doudaki, V. (2011). Representations of disease and threat: the case of swine flu in Greece and in Cyprus. In L. Baxter \& P. Braescu (Eds.), Fear within Melting Boundaries (pp. 191-201). Brill. https://brill.com/view/title/54909

Evlampidou, I., \& Kogevinas, M. (2019). Solidarity outpatient clinics in Greece: a survey of a massive social movement. Gaceta Sanitaria, 33(3), 263-267. https://doi.org/10.1016/j.gaceta.2017.12.001

Gamson, W. A. (1995). Constructing social protest. In H. Johnston \& B. Klandermans (Ed.) Social movements and culture (pp. 85-106). Minneapolis: University of Minnesota Press.

Gamson, W. A., \& Wolfsfeld, G. (1993). Movements and Media as Interacting Systems. The Annals of the American Academy of Political and Social Science, 528, 114-125.

Gitlin, T. (2003). The Whole World Is Watching: Mass Media in the Making and Unmaking of the New Left. University of California Press.

Golan, G. (2006). Inter-Media Agenda Setting and Global News Coverage. Journalism Studies, 7(2), 323-333. https://doi.org/10.1080/14616700500533643

Groshek, J., \& Groshek, M. C. (2013). Agenda Trending: Reciprocity and the Predictive Capacity of Social Networking Sites in Intermedia Agenda Setting across Topics over Time. Media and Communication, 1(1), 15-27. https://doi.org/10.17645/mac.v1i1.71

Heim, K. (2013). Framing the 2008 Iowa Democratic Caucuses: Political Blogs and Second-Level Intermedia Agenda Setting. Journalism \& Mass Communication Quarterly, 90(3), 500-519. https://doi.org/10.1177/1077699013493785

Kavoulakos, K. (2018). Social solidarity economy, crisis and social movements. In N. Serdedakis \& S. Tompazos (Eds.), Aspects of the Greek Crisis: Contentious Protest Cycle and Institutional Outcomes, [In Greek] (pp. 494-520). Athens: Gutenberg.

Kavoulakos, K., \& Gritzas, G. (2015). Movements and alternative spaces in crisisridden Greece: a new civil society. In N. Demertzis \& N. Georgarakis (Eds.), The political portrait of Greece: crisis and the deconstruction of the political (pp. 337-355). Athens: Gutemberg and National Centre for Social Research.

Kokkinidis, G. (2015). Spaces of possibilities: Workers' self-management in Greece. Organization, 22(6), 847-871. https://doi.org/10.1177/1350508414521098

Kotronaki, L., \& Christou, S. (2019). (De-)Politicization Trajectories in an Anti-Austerity Contentious Cycle. Social ClinicsPharmacies Solidarity structures in Greece. Partecipazione E Conflitto, 12(2), 325-352-352. https://doi.org/10.1285/i20356609v12i2p325

Kousis, M., \& Kanellopoulos, K. (2014). Impacts of the Greek Crisis on Contentious and Conventional Politics, 2010-2012., N. Petropoulos \& G. Tsobanoglou (Eds.) The Social Impacts of the Eurozone Debt Crisis [In Greek] (pp. 443-462). Athens: Gordios Books.

Kousis, M., \& Paschou, M. (2017). Alternative Forms of Resilience. A typology of approaches for the study of Citizen Collective Responses in Hard Economic Times. PARTECIPAZIONE E CONFLITTO, 10(1), 136-168-168. https://doi.org/10.1285/i20356609v10i1p135

Kretsos, L., \& Vogiatzoglou, M. (2015). Lost in the ocean of deregulation? : the Greek labour movement in a time of crisis. Relations Industrielles/Industrial Relations. https://doi.org/10.7202/1031484ar

Leandros, N., \& Papadopoulou, L. (2020) Strategic Business Models in Times of Transformational Change and Crisis: A New Typology for Sustainable Media. Journal of Media Management and Entrepreneurship 2(1), 28-41. doi: 
10.4018/JMME.2020010102.

Lee, B., Lancendorfer, K. M., \& Lee, K. J. (2005). Agenda-setting and the internet: The intermedia influence of internet bulletin boards on newspaper coverage of the 2000 general election in South Korea. Asian Journal of Communication, 15(1), 57-71. https://doi.org/10.1080/0129298042000329793

Lee, T. T. (2005). The Liberal Media Myth Revisited: An Examination of Factors Influencing Perceptions of Media Bias. Journal of Broadcasting \& Electronic Media, 49(1), 43-64. https://doi.org/10.1207/s15506878jobem4901_4

Lopez-Escobar, E., Llamas, J. P., McCombs, M., \& Lennon, F. R. (1998). Two Levels of Agenda Setting Among Advertising and News in the 1995 Spanish Elections. Political Communication, 15(2), $225-238$. https://doi.org/10.1080/10584609809342367

Maniou, T. A. (2017). From PSB to Privatisation: Structures and Vulnerabilities of the Greek-Cypriot Broadcasting Sector. VIEW Journal of European Television History and Culture, 6(11), 102-112. https://doi.org/10.18146/22130969.2017.jethc127

Maniou, T. A., \& Bantimaroudis, P. (2021). Hybrid salience: Examining the role of traditional and digital media in the rise of the Greek radical left. Journalism, 22(4), 1127-1144. https://doi.org/10.1177/1464884918796587

Marwell, T., \& Oliver, P. (1984). Collective Action Theory and Social Movements Research. In L. Kriesberg (Ed.), Research in Social Movements, Conflict and Change. Greenwich, CT: Jai Press.

McCaffrey, D., \& Keys, J. (2000). Competitive framing processes in the abortion debate: polarization-vilification, frame saving, and frame debunking. The Sociological Quarterly, 41(1), 41-61. https://doi.org/10.1111/j.15338525.2000.tb02365.x

McCombs, M. (2014). Setting the Agenda: Mass Media and Public Opinion (2nd ed.). Polity.

McCombs, M. E., \& Shaw, D. L. (1972). The Agenda-Setting Function of Mass Media. The Public Opinion Quarterly, 36(2), 176-187.

Meraz, S. (2009). Is There an Elite Hold? Traditional Media to Social Media Agenda Setting Influence in Blog Networks. Journal of Computer-Mediated Communication, 14(3), 682-707. https://doi.org/10.1111/j.1083-6101.2009.01458.x

Messner, M., \& Distaso, M. W. (2008). The Source Cycle. Journalism Studies, 9(3), $447-463$. https://doi.org/10.1080/14616700801999287

Messner, M., \& Garrison, B. (2011). Study Shows Some Blogs Affect Traditional News Media Agendas. Newspaper Research Journal, 32(3), 112-126. https://doi.org/10.1177/073953291103200309

Mylonas, Y. (2014). Crisis, Austerity and Opposition in Mainstream Media Discourses of Greece. Critical Discourse Studies, 11(3), 305-321. https://doi.org/10.1080/17405904.2014.915862

Neuman, W. R., Guggenheim, L., Jang, S. M., \& Bae, S. Y. (2014). The Dynamics of Public Attention: Agenda-Setting Theory Meets Big Data. Journal of Communication, 64(2), 193-214. https://doi.org/10.1111/jcom.12088

Panayiotakis, M. (2015). The Radical Left in Greece. Socialism and Democracy, 29(3), $25-43$. https://doi.org/10.1080/08854300.2015.1090833

Papadopoulou, L. (2015). How Media In Greece Reported The Migration Crisis. European Journalism Observatory. Retrieved January 20, 2021 https://en.ejo.ch/media-politics/media-greece-reported-migration-crisis

Papadopoulou, L. (2019). Democracy and media transparency: Systemic failures in Greek radio ecosystem and the rise of alternative and radical web radio. In Chaparro Escudero, M., Gabilondo, V., Espinar Medina, L. (Eds). Transparecia, mediatica, oligopolios, y Democracia., (pp. 211-218), Spain: Communication Social.

Papadopoulou, L. (2020). Alternative hybrid media in Greece: An analysis through the prism of political economy. Journal of Greek Media and Culture 6(2), 199-218. d https://doi.org/10.1386/jgmc_00013_1

Papadopoulou. L., \& Maniou, T. (2020). Affective labour and perceptions of trauma journalism in crisis-ridden countries. In Karatzogianni, A. \& Veneti, A. (Eds), The Emerald Handbook of Digital Media in Greece: Journalism and Political Communication in Times of Crisis, (pp. 179-195). United Kingdom: Emerald Group Publishing.

Psimitis, M. (2011). The Protest Cycle of Spring 2010 in Greece. Social Movement Studies, 10(2), $191-197$. https://doi.org/10.1080/14742837.2011.562365

Ragas, M. W., \& Kiousis, S. (2010). Intermedia Agenda-Setting and Political Activism: MoveOn.org and the 2008 Presidential Election. Mass Communication and Society, 13(5), 560-583. https://doi.org/10.1080/15205436.2010.515372 
Roberts, M. S., \& Bantimaroudis, P. (1997). Gatekeepers in International News: The Greek Media. Harvard International Journal of Press/Politics, 2(2), 62-76. https://doi.org/10.1177/1081180X97002002006

Rogstad, I. (2016). Is Twitter just rehashing? Intermedia agenda setting between Twitter and mainstream media. Journal of Information Technology \& Politics, 13(2), 142-158. https://doi.org/10.1080/19331681.2016.1160263

Rohlinger, D. A. (2002). Framing the Abortion Debate: Organizational Resources, Media Strategies, and MovementCountermovement Dynamics. The Sociological Quarterly, 43(4), 479-507. Retrieved from JSTOR

Rucht, D. (2003). Violence and New Social Movements. In W. Heitmeyer \& J. Hagan (Eds.), International Handbook of Violence Research (pp. 369-382). Springer Netherlands. https://doi.org/10.1007/978-0-306-48039-3_20

Rucht, D. (2013). Protest movements and their media usages. In B., Cammaerts, Mattoni A. \& McCurdy, P. (Eds.), Mediation and protest movements (pp 249-268). Intellect Ltd.

Serdedakis, N., \& Tompazos, S. (2018). Introduction: Greek crisis and the social protest, In N. Serdedakis \& S. Tompazos (Ed.) Aspects of the Greek Crisis: Contentious Protest Cycle and Institutional Outcomes pp. 11-35. Athens: Gutenberg [In Greek].

Shoemaker, P. J., \& Reese, S. D. (2013). Mediating the Message in the 21st Century: A Media Sociology Perspective. Routledge.

Smith, J., McCarthy, J., Mcphail, C., \& Augustyn, B. (2001). From Protest to Agenda Building: Description Bias in Media Coverage of Protest Events in Washington, D.C. Social Forces, 79, 1397-1423. https://doi.org/10.1353/sof.2001.0053

Staggenborg, S. (1998). Social Movement Communities and Cycles of Protest: The Emergence and Maintenance of a Local Women's Movement. Social Problems, 45(2), 180-204. https://doi.org/10.2307/3097243

Staggenborg, S., \& Lecomte, J. (2009). Social Movement Campaigns: Mobilization and Outcomes in the Montreal Women's Movement Community. Mobilization, 14, 163-180. https://doi.org/10.17813/maiq.14.2.0414240734477801

Stavrakakis, Y., \& Galanopoulos, A. (2019). Discursive uses of “abnormality”. In, K. Power, T. Ali \& E. Lebdušková (Ed.) Discourse Analysis and Austerity: Critical Studies from Economics and Linguistics pp. 177-195. Routledge.

The cleaning ladies in New York Times (2014, June 13). Kathimerini [In Greek]. https://www.kathimerini.gr/world/771576/oi-katharistries-stoys-new-york-times/

Trumbo, C. (1995). Longitudinal Modeling of Public Issues: An Application of th Agenda-Setting Process to the Issue of Global Warming. Journalism and Communication Monographs, 152.

Tsavdaroglou, C., Petrakos, K., \& Makrygianni, V. (2017). The golden 'salto mortale' in the era of crisis. City, 21(3-4), 428447. https://doi.org/10.1080/13604813.2017.1331563

Vamvakas, V., \& Dimitrakopoulou, D. (2015). The online "factor" in the intermedia agenda-setting: The case of the Greek Indignant Citizens Movement. In J. Dee \& S. Drucker (Eds.) From Tahrir Square to Gezi Park: Social Networks as Facilitators of Social Movements. Oxford: Peter Lang.

Vonbun, R., Königslöw, K. K., \& Schoenbach, K. (2016). Intermedia agenda-setting in a multimedia news environment. Journalism, 17(8), 1054-1073. https://doi.org/10.1177/1464884915595475

Walgrave, S., \& Vliegenthart, R. (2012). The Complex Agenda-Setting Power of Protest: Demonstrations, Media, Parliament, Government, and Legislation in Belgium, 1993-2000. Mobilization: An International Quarterly, 17. https://doi.org/10.17813/maiq.17.2.pw053m281356572h

Weaver, D. H. (2016). Agenda-Setting. In The International Encyclopedia of Political Communication (pp. 1-9). American Cancer Society. https://doi.org/10.1002/9781118541555.wbiepc016

Whitney, D. C., \& Becker, L. B. (1982). 'Keeping the Gates' for Gatekeepers: The Effects of Wire News. Journalism Quarterly, 59(1), 60-65. https://doi.org/10.1177/107769908205900109

Zamponi, L., \& Bosi, L. (2018). Politicizing Solidarity in Times of Crisis: The Politics of Alternative Action Organizations in Greece, Italy, and Spain. American Behavioral Scientist, 62(6), 796-815. https://doi.org/10.1177/0002764218768861

\section{Copyrights}

Copyright for this article is retained by the author(s), with first publication rights granted to the journal.

This is an open-access article distributed under the terms and conditions of the Creative Commons Attribution license which permits unrestricted use, distribution, and reproduction in any medium, provided the original work is properly cited. 